\title{
Vuorovaikutuksen näkökulma toimivaan työelämän yhteistyöhön
}

\author{
Annaleena Aira
}

Lectio praecursoria puheviestinnän väitöskirjaksi tarkoitetun tutkimuksen Toimiva yhteistyö - työelämän vuorovaikutussuhteet, tiimit ja verkostot tarkastustilaisuudessa Jyväskylän yliopistossa 3.5.2012. Vastaväittäjänä toimi professori Sanna Järvelä (Oulun yliopisto) ja kustoksena professori Maarit Valo.

Työelämässä yhteistyö on noussut merkittäväksi menestystekijäksi. Moniammatilliselta ja perinteisten teollisuusalojen rajat ylittävältä yhteistyöltä odotetaan ratkaisuja yhteiskunnallisiin ongelmiin ja Suomen kilpailukykyyn. Yhteistyökykyä edellytetään yhä useammissa työtehtävissä, ja yhteistyötaidot ovatkin jo lasten varhaiskasvatuksen tavoitteina.

Parhaillaan Suomessa valmistellaan osana hallitusohjelmaa työelämän kehittämisstrategiaa, jonka tavoitteena on Euroopan paras työelämä. Pari viikkoa sitten raportoidussa strategian pohjaksi tehdyssä kansalaiskyselyssä korostuneen merkityksellisiksi nousivat luottamus ja yhteistyön vahvistuminen työelämässä.

Mitä tämä yhteistyö tarkemmin katsottuna on, miten sitä työelämässä toteutetaan, ja voiko yhteistyötä kehittää? Eri tieteenalojen yhteistyötutkimuksissa on keskitytty ennen kaikkea yhteistyön rakenteiden tarkasteluun: esimerkiksi miten verkoston keskittyneisyys tai tiimin koko vaikuttaa yhteistyöhön. Minua kiinnostaa yhteistyön prosessi eli se, miten yhteistyötä oikeastaan toteutetaan. Lähdin tutkimuksessani liikkeelle määritelmästä, jonka mukaan yhteistyö on aktiivinen ja tavoitteellinen prosessi, joka syntyy toiveesta tai tarpeesta luoda jotain uutta tai ratkaista jokin ongelma.

Yhteistyötä tehdessään yhteistyön osapuolet ovat useimmiten tavalla tai toisella yhteydessä toistensa kanssa. Havaitsin, että ihmisten välisen vuorovaikutuksen tutkimus antaa työkalut yhteistyöprosessin tarkasteluun. Vuorovaikutuksen jäsennysten avulla pystytään tunnistamaan, nimeämään ja ymmärtämään sellaisia yhteistyöprosessin ilmiöitä, jotka muuten saattaisivat jäädä abstrakteiksi ja vaikeasti tavoitettaviksi.

Aiemmat yhteistyötutkimukset on toteutettu usein opiskelijaryhmillä sen sijaan, että olisi tutkittu oikean työelämän aitoja yhteistyötilanteita. Useimmiten tutkimusmenetelmät ovat painottuneet keinotekoisiin, siis tutkimusta varten pystytettyihin yhteistyötilanteisiin, tai yhteistyön yhden osapuolen näkemysten selvittämiseen tavallisimmin kyselylomakkeiden avulla. Ja vaikka maantieteel- 
lisesti ja organisatorisesti hajautunut yhteistyö on jatkuvasti yleistynyt, yllättävän usein tutkimukset tarkastelevat yhteistyötä vain kasvokkaistilanteissa huomioimatta viestintäteknologian välityksellä tapahtuvaa yhteydenpitoa kasvokkaistapaamisten välillä.

Minulle tarjoutui mahdollisuus tehdä väitöstutkimukseni oikeasta työelämän yhteistyöstä, joka on hajautunut sekä maantieteellisesti eri paikkakunnille että organisatorisesti eri yrityksiin, kun tulin Elintarvikekehityksen klusterin tiedottajaksi Foodwest Oy:öön Seinäjoelle muutama vuosi sitten. Elintarvikekehityksen klusteri kuuluu yhtenä kolmestatoista valtakunnallisesti toimivasta klusterista työ- ja elinkeinoministeriön koordinoimaan Osaamiskeskusohjelmaan, joka hyvin pian herätti minussa tutkijan mielenkiinnon. Osaamiskeskusohjelma aineistonkeruuympäristönä suuntasi tutkimuskontekstin asiantuntijatyöhön. Olen siis toiminut kaksoisroolissa tutkijana ja tiedottajana Osaamiskeskusohjelmassa. Elintarvikekehityksen klusteri ei kuitenkaan ole ollut mukana tutkimukseni aineistossa.

Yhteistyö-sanaan liittyy arkikielessäkin runsaasti myönteisiä mielleyhtymiä. Tutkimuksissakin yhteistyöhön on suhtauduttu ajoittain varsin kritiikittömästi. Oma lähtökohtani on, että työelämän resurssipaineissa "mitä enemmän tai tiiviimpää yhteistyötä, sen parempi" ei ole kovin realistinen tavoite. Tärkeää on löytää tasapaino tulosten saavuttamisen ja resurssien käytön välille. Tavoitteita toteuttavaa ja kaikille osapuolille sopivaa yhteistyötä kutsun toimivaksi yhteistyöksi.

\section{Tutkimuksen tavoitteet}

Tutkimukseni ensimmäisenä tavoitteena oli ymmärtää ja kuvata työelämän yhteistyötä käsitteenä ja ilmiönä sekä tarkastella yhteistyön suhdetta vuorovaikutukseen. Tutkin, miten yhteistyö toteutuu osapuolten välisessä vuorovaikutuksessa ja millaiset vuorovaikutuksen ilmiöt ovat yhteydessä toimivaan yhteistyöhön.

Tutkimukseni toisena tavoitteena oli selvittää teknologiavälitteisen vuorovaikutuksen hyödynnettävyyttä hajautuneessa yhteistyössä. Tutkin sitä, mikä on teknologiavälitteisen vuorovaikutuksen rooli hajautuneen yhteistyön edistämisessä. Teknologiavälitteisellä vuorovaikutuksella tarkoitan ihmisten yhteydenpitoa toistensa kanssa erilaisten viestintävälineiden, kuten puhelimen, sähköpostin tai videoyhteyden välityksellä.

Tutkimustavoitteet johdattivat minut tutkimaan toimivaa yhteistyötä kvalitatiivisella tutkimusotteella. Voidakseni ymmärtää ja kuvata toimivaa työelämän yhteistyötä ja sen toteutumista vuorovaikutuksessa päätin sekä havainnoida yhteistyön osapuolten välistä vuorovaikutusta että selvittää haastattelemalla yhteistyön eri osapuolten näkemyksiä.

Tutkimuksen osallistujiksi valikoitui ministeriön toteuttaman viestintäkyselyn perusteella neljä osaamisklusteria kolmestatoista. Näissä neljässä klusterissa toteutin teemahaastattelut (haastateltavia oli yhteensä 20) ja teknologiavälitteisen 
vuorovaikutuksen observoinnin (osallistujia oli yhteensä 25). Tutkimuseettisistä syistä en ole julkistanut klusterien nimiä.

\section{Työelämän yhteistyötä toteutetaan vuorovaikutuksessa}

Yhteistyö kuuluu nykypäivän asiantuntijatyöhön erottamattomasti. Yhteistyö näyttäytyy kielteisimmillään työaikaa tuhlaavana ylimääräisenä rasitteena. Tämä turhauttaa asiantuntijoita etenkin, jos yhteistyön ei koeta tuottavan tuloksia. Myönteisimmillään yhteistyö koetaan oman työn kannalta ensiarvoisen tärkeäksi. Yhteistyöllä koetaan saavutettavan tuloksia, jotka eivät yksin olisi tavoitettavissa kovallakaan työllä.

Yhteistyön määritelmään sisältyy yhteisten tavoitteiden olemassaolo. Organisaatioiden välisessä yhteistyössä tavoitteen löytäminen ei kuitenkaan ole itsestäänselvyys, vaan se saattaa edellyttää runsaastikin vuorovaikutusta, jotta voidaan nähdä, mihin yhteistyöllä voitaisiin päästä ja kannattaako siihen pyrkiä.

Yhteistyö toteutuu osapuolten välisessä vuorovaikutuksessa. Vuorovaikutus luo, muokkaa ja ylläpitää yhteistyöprosessia. Toimiva yhteistyö edellyttää riittävää määrää vuorovaikutusta tarpeeksi usein. Hajautunut yhteistyö edellyttää siten käytännössä aina myös teknologiavälitteistä vuorovaikutusta ollakseen toimivaa.

Yhteistyötä tehdessään ihmiset muodostavat ja ylläpitävät vuorovaikutussuhteita, tiimejä ja verkostoja. Tutkimuksessani löysin kullekin näistä kolmesta näkökulmasta tyypillisiä vuorovaikutuksen ilmiöitä, jotka ovat yhteydessä toimivaan yhteistyöhön.

\section{Kahdenvälisissä vuorovaikutussuhteissa tiivistä ja tuloksellista yhteistyötä}

Eniten resursseja vievä, mutta tiivein ja tuloksellisin yhteistyö toteutuu kahden ihmisen välisissä vuorovaikutussuhteissa. Työelämän yhteistyössä ihmisten välille muodostuu monenlaisia, eri tavoin toimivia vuorovaikutussuhteita. Merkityksellinen vuorovaikutussuhde voi toimia yhteistyön osapuolelle oman asiantuntemuksen laajentajana, tiedon lähteenä, ideoinnin alustana, tuen tarjoajana ja ongelmanratkaisuun haastajana. Vuorovaikutussuhteiden näkökulmasta toimiva yhteistyö edellyttää luottamuksen rakentamista, vuorovaikutussuhteiden ylläpitoa ja tasapainoilua suhteessa koetun etäisyyden ja läheisyyden välillä.

Luottamuksen merkitys yhteistyölle on suuri. Tämä on todettu myös aiemmassa tutkimuksessa. Luottamusta rakennetaan ihmisten välisessä vuorovaikutuksessa. Pohjimmiltaan luottamus rakentuu myös tiimeissä ja verkostoissa kahden ihmisen välille osana vuorovaikutussuhteen muodostumisen ja ylläpitämisen prosessia. Erityisen näkyväksi luottamuksen rakentumisen tarve nousee 
teknologiavälitteisessä yhteistyössä, jossa on luotava riittävästi vuorovaikutuksen mahdollisuuksia, jotta luottamus voi rakentua.

Vuorovaikutussuhteen ylläpito toteutuu hajautuneessa yhteistyössä pääosin tiiviin, monipuolisen ja merkityksellisen teknologiavälitteisen vuorovaikutuksen avulla. Työelämän yhteistyösuhteissa vuorovaikutussuhteen ylläpidon kannalta yksityisasioista puhumista merkittävämmäksi osoittautui työn kannalta merkityksellinen tehtäväkeskeinen vuorovaikutus. Esimerkiksi uusia ideoita tuottavissa vuorovaikutussuhteissa suhteen ylläpidon kannalta merkittävää on testata omia ideoita tai kehitellä ajatuksia yhdessä.

Yhteistyökumppanit joutuvat tasapainoilemaan ylläpitääkseen molemmille sopivaa sosiaalista välimatkaa vuorovaikutussuhteessaan. Liiallinen etäisyys hankaloittaa yhteydenpitoa ja sitä kautta yhteistyömahdollisuuksien avautumista, mutta liiallinen läheisyyskään ei edistä yhteistyötä: se voi viedä liikaa resursseja, aiheuttaa huonoja päätöksiä liiallisen samanmielisyyden takia tai hankaloittaa puolueetonta suhtautumista.

\section{Passiivisuus teknologiavälitteisessä vuorovaikutuksessa tiimien yhteistyön haasteena}

Tiimien näkökulma tulee tutkimuksessani esille erityisesti klusterien ydintiimien eli johtoryhmien kautta. Nämä ovat pitkäkestoisia tiimejä, jotka ovat hajautuneet organisatorisesti ja maantieteellisesti. Vastaavanlaisia ydintiimejä voitaneen tunnistaa monista yhteistyöverkostoista. Tiimi voi olla hyvä foorumi erilaisten näkemysten esille tuomiselle, yhteisten merkitysten muodostamiselle, ideoinnille ja uusien ajatusten kehittelylle ja ongelmanratkaisulle.

Tiimien näkökulmasta toimiva työelämän yhteistyö edellyttää tiimiytymistä, hyviä vuorovaikutuskäytänteitä ja aktiivista johtamista.

Tehokas yhteistyö edellyttää tiimien muodostumista eli tiimiytymistä, muuten osapuolet jäävät toisistaan erilleen. Tiimiytymistä näyttää hidastavan erityisesti epäsäännöllinen ja satunnaisesti toistuva vuorovaikutus. Viestintäteknologiaa voidaan hyödyntää tiimiytymisprosessin tukemiseen. Tämä koskee yhtä lailla fyysisesti lähekkäin toimivia kuin eri tavoin hajautuneita työryhmiä.

Yllättävä huomio tutkimuksessani oli monien asiantuntijoiden passiivisuus tiiminsä teknologiavälitteisessä vuorovaikutuksessa. Viestintävälineiden käytön sulauttaminen osaksi jokapäiväisiä työrutiineja osoittautui tärkeäksi mutta haasteelliseksi. Tiimien kannattaa kiinnittää huomiota vuorovaikutuskäytänteisiinsä, kuten mistä ja miten puhutaan, mitä viestintävälineitä käytetään, milloin ollaan yhteydessä ja miten nopeasti vastataan. Vuorovaikutuskäytänteistä sopiminen voi auttaa keskittymään tavoitteiden kannalta olennaisiin asioihin.

Tiimin johtajan rooli yhteistyön edistämisessä on suuri, ja tiimin johtajat olivatkin tutkimuksessani runsaiden ja ristiriitaisten odotusten kohteena. Johtajan työlle haasteita tuovat yhteistyön hajautuneisuus, esimiesvallan puuttumi- 
nen ja asiantuntijoiden johtaminen. Vahvaa johtajuutta osoitetaan hajautuneessa ympäristössä aktiivisuudella. Vaikea tavoitettavuus ja viesteihin vastaamattomuus herättivät vahvaa tyytymättömyyttä tiimin jäsenissä.

\section{Verkostoyhteistyö edellyttää kilpailun hallintaa ja erilaisuuden hyödyntämistä}

Verkoston näkökulma selittää monen organisaation välistä monimutkaista yhteistyörakennetta. Verkoston näkökulmasta yhteistyön toimivuuden kannalta keskeistä on hallita keskinäistä kilpailua, hyödyntää yhteistyön osapuolten erilaisuutta ja suunnata vuorovaikutusta pelkästä suunnittelusta toteutukseen.

Yhteistyön osapuolten keskinäinen kilpailu ei lopu yhteistyön aloittamiseen, vaan on tyypillistä yhteistyölle erityisesti verkostoyhteistyössä, jossa ovat läsnä useamman organisaation tavoitteet yhteisten tavoitteiden rinnalla. Verkostoyhteistyö edellyttää aiemmin erillään toimineilta osapuolilta uudenlaisia toimintatapoja. Siirtyminen organisaatiolähtöisyydestä kohti toimivaa yhteistyötä vaatii yhteistyökumppaneilta yhteistyöhakuisuutta. Verkoston yhteistyömahdollisuuksia näyttävät pystyvän parhaiten hyödyntämään ne toimijat, jotka kertovat avoimesti omista ja oman organisaationsa tavoitteista, taustoista ja rajoituksista.

Yhteistyön osapuolten erilaisuuden koetaan hankaloittavan yhteistyötä. Erilaisten taustaoletusten vuoksi yhteisymmärryksen saavuttaminen ei ole helppoa. Yhteistyökumppaneiden erilaisuus voi näkyä erimielisyyksinä, konfliktei-na ja väärinymmärryksinä. Se voi tuoda yhteistyöhön myös moniäänisyyttä, uutta tietoa ja uusia käytänteitä sekä auttaa kyseenalaistamaan toimintamalleja ja ajatustapoja. Erilaisuuden hyödyntäminen tapahtuu tuomalla esille erilaisia näkemyksiä ja valjastamalla erilaisia vahvuuksia yhteisten tavoitteiden eteen. Edellytyksenä on yhteisten merkitysten muodostaminen, mikä vaatii toistuvaa ja jatkuvaa vuorovaikutusta ja usein myös rakentavaa erimielisyyksien käsittelyä.

Toimivassa yhteistyössä onnistutaan siirtymään suunnittelusta tulosten tuottamiseen. Tämä edellyttää yhteisten tavoitteiden löytämistä, joita kohti voidaan yhteistyöllä pyrkiä. Joskus avain verkostoyhteistyön tuloksellisuuden lisäämiseen voi olla panostaminen verkoston sisäisten tiimien ja vuorovaikutussuhteiden toimintaan.

Organisaatioiden välisen yhteistyön tutkiminen vuorovaikutuksen näkökulmasta osoittautui erittäin mielenkiintoiseksi tutkimuskohteeksi. Tutkimukseni herätti suuren joukon uusia kysymyksiä ja jatkotutkimushaasteita. Jo pelkästään suomalaisessa työelämässä olisi useita kiinnostavia ympäristöjä, joissa tutkimuksessani havaittuihin, toimivan yhteistyön kannalta tärkeisiin vuorovaikutushaasteisiin voitaisiin syventyä tarkemmin. Uskon, että yhteistyön toteuttamista tarkastelevista tutkimuksesta on hyötyä työelämälle erilaisten yhteistyötapojen kehittämisessä. 